\title{
Uji Daya Hambat Fungisida Nabati terhadap Colletotrichum sp. dan Sclerotium sp. Secara In-Vitro
}

\section{In-Vitro Test of Botanical Pesticides Against Colletotrichum sp. and Sclerotium sp.}

\author{
Neli Afrianti ${ }^{1}$, Muhammad Taufik ${ }^{2 *}$, Gusnawaty $\mathrm{HS}^{2}$, Andi Khaeruni ${ }^{2}$ dan Asniah $^{2}$ \\ ${ }^{1}$ Program Studi Magister Agronomi Pascasarjana Universitas Halu Oleo \\ 2 Jurusan Proteksi Tanaman Fakultas Pertanian Universitas Halu Oleo
}

Diterima: 27 Juli 2021 / Disetujui: 30 September 2021

\begin{abstract}
ABSTRAK
Buah tomat memiliki kandungan vitamin C, B-carotene, lycopene yang penting bagi kesehatan. Selain itu nilai ekonomi tomat juga cukup tinggi sehingga menarik banyak petani untuk membudidayakannya. Saat ini petani tomat menghadapi kendala yaitu serangan penyakit bercak daun yang dapat disebabkan oleh beberapa patogen seperti Alternaria sp., Colletotrichum sp., Sclerotium sp., dan Pestaliopsis sp.Kompleks patogen tersebut menyulitkan petani tomat untuk mengendalikannya. Alternatif yang ditawarkan adalah penggunaan pestisida nabati berbahan minyak cengkeh dan ekstrak kulit jambu mete-phymar. Tujuan penelitian adalah mengevaluasi kemampuan fungisida nabati untuk mengendalikan patogen penyebab bercak daun tomat. Penelitian menggunakan Rancangan Acak Lengkap (RAL) dengan tujuh perlakuan yaitu kontrol (N0), pestisida sintetik $2 \mathrm{~mL}(\mathrm{~N} 1)$ phymar $10 \mathrm{~mL}(\mathrm{~N} 2)$, phymar $20 \mathrm{~mL}$ (N3), phymar $30 \mathrm{~mL}$ (N4), minyak cengkeh 2,5 mL (N5), minyak cengkeh $5 \mathrm{~mL}$ (N6) dan minyak cengkeh $7 \mathrm{~mL}$ (N7), setiap perlakuan diulang empat kali. Hasil penelitian menunjukkan bahwa perlakuan fungisida nabati phymar dan minyak cengkeh mampu menghambat pertumbuhan cendawan patogen Colletotrichum sp dan Sclerotium sp. Fungisida nabati minyak cengkeh dengan konsentrasi $2,5 \mathrm{ml} / \mathrm{L}$ media agar sudah efektif menghambat perkembangan Colletotrichum $\mathrm{sp}$ dan Sclerotium sp. secara in-vitro dengan daya hambat masing-masing sebesar $100 \%$.
\end{abstract}

Kata kunci : bercak daun, Colletotrichum., fungisida, Sclerotium

\section{ABSTRACT}

Tomato plants contain vitamin $C$, $\beta$-carotene, lycopene which isessential for health. In addition, the economic value of tomatoes is also high enough to attract many farmers to cultivate them. Currently, tomato farmers are toward leaf spot disease caused by several pathogens such as Alternaria sp., Colletotrichum sp., Sclerotium sp., and Pestaliopsis sp. This complex of pathogens makes it difficult for tomato growers to control it. The alternative offered is the use of botanical pesticides made from clove oil and cashew nut peel extract-phymar. The study used a completely randomized design (CRD) with, seven treatments e.i. control (N0), synthetic pesticide $2 \mathrm{~mL}$ (N1) phymar $10 \mathrm{~mL}$ (N2), phymar $20 \mathrm{~mL}$ (N3), phymar $30 \mathrm{~mL}$ (N4), cloves oil $2.5 \mathrm{~mL}$ (N5), clove oil $5 \mathrm{~mL}$ (N6), and clove oil $7 \mathrm{~mL}$ (N7), each treatment repeated four times. The results showed that the treatment of botanical fungicide phymar and clove oil could inhibit the growth of the pathogenic fungi Colletotrichum sp. and Sclerotium sp. Botanical pesticide made from clove oilwith a concentration of $2.5 \mathrm{ml} / \mathrm{l}$ agar medium was effective in inhibiting the development of the pathogenic fungus Colletotrichum sp. and Sclerotium sp. cause leaf spot disease in tomato plants in-vitro $100 \%$.

Keywords: Colletotrichum, leaf spot, pesticide, sclerotium

*Penulis untuk korespondensi, E-mail : taufik24@yahoo.com

\section{PENDAHULUAN}

Tanaman tomat (Lycopersicum esculentum Mill) memiliki nilai ekonomi yang cukup tinggi, sehingga menarik petani untuk membudidayakan dan berpotensi sebagai produk ekspor (Susana et al.
2010). Penggunaan tomat semakin luas karena memiliki prospek bisnis yang cerah bagi petani tomat maupun masyarakat pada umumnya.Meskipun demikian, tingkat konsumsi sayuran di Indonesia masih di bawah standar. Standar konsumsi sayuran di Indonesia berdasarkan 
anjuran Food and Agriculture Organization yaitu 75 $\mathrm{kg}$ per kapita per tahun (FAO, 2010). Tomat juga penting bagi kesehatan karena vitamin $\mathrm{C}$ dan mineral yang berkontriubusi penting terhadap kesehatan manusia. Kandungan vitamin C mencapai $17.6 \mathrm{mg} / 100 \mathrm{~g}$, ß-carotene 19.84 (mg/kg), lycopene $112 \mathrm{mg} / \mathrm{kg} \mathrm{112}$, yang menarik lycopene adalah antioksidan yang penting bagi kesehatan untuk mencegah berbagai penyakit (Soare et al., 2018). Selain itu tomat dapat juga dikonsumsi sebagai buah segar atau dibuat untuk dikonsumsi sebagai sayuran.

Berdasarkan data tahun 2019, produktivitas tomat Indonesia sebesar18,63 ton/ha, terdapat peningkatan produktivitas dibandingkan dengan tahun 2018 yaitu 18,04 dan tahun 2017 yaitu 17,31 ton/ha.Hasil produktivitas tomat provinsi Sulawesi Tenggara pada tahun 2019 sebesar 3,89ton/ha, ada peningkatan produktivitas dibandingkan dengan tahun 2018 sebesar 2,98ton/ha dan tahun 2017 sebesar 2,83ton/ha tetapi pada tahun 2016 sebesar 5,10 ton/ha. Peningkatan hasil produktivitas pada tahun 2019 belum sebanding dengan hasil produktivitas tahun 2016 (Kementan RI, 2020).

Salah satu penyebab masih rendahnya produktivitas tomat di Sulawesi Tenggara karena adanya infeksi penyakit seperti bercak daun (Alternaria solani), busuk daun (Phytophthora infestans), kapang daun (Fulvia fulva), layu fusarium (Fusarium oxysporum), busuk buah (Sclerotium rolfsii), layu bakteri (Ralstonia solanacearum) dan antraknosa (Colletotrichum sp.) (Semangun, 2007). Gulzar et al. (2018) melaporkan kehilangan hasil tahunan yang diakibatkan oleh cendawan patogen mencapai $79 \%$ di Amerika Serikat, Aftustralia, Israel, Inggris dan India. Hasil pengamatan yang telah dilakukan oleh tim peneliti pada pertanaman tomat di Kecamatan Konda dan Wolasi, Kabupaten Konawe Selatan, kerugian yang ditimbulkan lebih dari $50 \%$ (data belum dipublikasi).

Infeksi awal Colletotrichum sp.dimulai dengan konidia, kemudian konidia berkecambah pada permukaan tanaman dan menghasilkan tabung kecambah. Setelah penetrasi maka akan terbentuk jaringan hifa. Hifa intra dan interseluler menyebar melalui jaringan tanaman (Kronstad, 2000). Gejala penyakit Colletotrichum sp. dapat dilihat pada daun muda yang sudah membuka sempurna, meskipun spora sudah menempel sejak masih berupa calon daun. Daun muda lebih rentan terhadap infeksi Colletotrichum sp.dibandingkan dengan daun tua. Gejala nekrotik berwarna cokelat sampai hitam, muncul 2-4 hari setelah penetrasi spora. Penyakit bercak dapat menyerang daun, batang, buah dan bunga tanaman. Penyebaran spora patogen ini dapat melalui tanah, angin, air atau serangga(Anggraeni, 2009).

Cendawan Sclerotium sp. umumnya tidak hanya menginfeksi bagian daun tanaman, melainkan juga menginfeksi pangkal batang, akar, buah, daun dan bunga (Akarapisan et al. 2017). Sclerotiumsp.menyebabkan busuk pada batang tanaman tomat, sehingga pengangkutan air dan hara dari akar ke seluruh bagian tanaman menjadi terganggu. Batang yang terinfeksi akan terlihat ditumbuhi dengan benang-benang yang berwarna putih (miselia). Tanaman inang yang terserang oleh cendawan ini akan menunjukkan suatu gejala seperti terlihat cendawan berkembang pada batang tanaman yang berada pada bagian atau dekat dengan permukaan tanah, daun terlihat seperti tersiram air panas. Serangan lebih lanjut pada batang dan beberapa daun pada bagian bawah akan menyebkan tanaman layu dan mati (Sukamto dan Wahyuno, 2016).

Tanaman tomat yang terinfeksi pathogen Sclerotium sp. menimbulkan gejala busuk pada batang, daun tanaman layu dan akhirnya tamaman mati (Ferreira and Boley, 2006). Pengendalian penyakit bercak pada umumnya petani masih menggunakan fungisida sintetis.Penggunaan fungisida sintetis secara terus-menerus dapat menyebabkan resistensi patogen, keracunan pada manusia dan mencemari lingkungan (Hadizadeh et al., 2009).Diperlukan upaya pengendaliaan menjadi sesuatu yang harus dilakukan untuk itu mengurangi kehilangan hasil tanaman tomat.

Salah satu cara pengendalian penyakit tanaman yang lebih ramah lingkungan adalah penggunaan fungisida nabati minyak cengkeh atau Pymar yang diekstrak dari kulit jambu mete.Fungisida nabati ini dapat mengendalikan penyakit tananan dan tidak toksik terhadap agens hayati lainnya. Minyak atsiri yang diekstrak dari tanaman cengkeh mampu menekan pertumbuhan koloni Fusarium oxysporum yang menyerang buah cabai (Istianto dan Emilda 2008). Perendaman benih tomat dalam minyak cengkeh dengan konsentrasi $0.5 \%$ dapat mengeliminasi bakteri Clavibacter michiganensis subsp. michiganensis lebih dari 99\% (Zainal et al. 2010). Selain itu dilaporkan, minyak cengkeh tidak toksik terhadap agens hayati seperti Gliocladium sp. Konsentrasi 3 $\mu 1,9 \mu \mathrm{l}$ dan $18 \mu \mathrm{l}$ minyak cengkeh/ $10 \mathrm{ml}$ media tidak mempengaruhi pertumbuhan miselium agens hayati Gliocladium sp. dan campuran keduanya dapat menghambat pertumbuhan cendawan Fusarium oxysporum (Emilda dan Istianto 2011). Phymar yang mengandung asam anacardat $90 \%$ dan minyak 
cardol $10 \%$ dapat menekan pertumbuhan Phytopthora palmivora (Gusnawaty et al., 2013). Oleh karena itu tujuan penelitian ini adalah mengevaluasi kemampuan fungisida nabati berbahan minyak cengkeh dan kulit jambu metephymar untuk menghambat pertumbuhan Colletotrichum sp. dan Sclerotium sp. secara invitro.

\section{METODE PENELITIAN}

\section{Tempat dan Waktu}

Penelitian dilaksanakan dengan mengambil sampel daun tomat yang bergejala hawar daun pada pertanaman tomat di Konawe Selatan. Isolasi dan identifikasi patogen penyebab hawar daun dan uji daya hambat fungisida nabati terhadap patogen tersebut dilakukan di Laboratorium Proteksi Tanaman Unit Pendidikan dan Fitopatologi Fakultas Pertanian Universitas Halu Oleo. Penelitian berlangsung dari bulan Juni 2020 sampai Februari 2021.

\section{Bahan dan Alat}

Bahan yang digunakan dalam penelitian yaitu media Potato Dextrose Agar (PDA), minyak cengkeh, Phymar, alkohol $70 \%$, spritus, plastik wrap, plastik tahan panas, aluminium foil, kapas, dan aguadest. Alat yang digunakanadalah laminar air flow, pipet mikro, cawan petri, gelas ukur, jarum ose, hot plate, autoclave, dan botol schott.

\section{Survei dan Isolasi Patogen Penyebab Penyakit Bercak Daun}

Pengambilan sampel tanaman tomat bergejala hawar/bercak daun dilakukan di dua lokasi yang berbeda di sentra pertanaman tomat yakni di Kecamatan Konda dan Wolasi Kabupaten Konawe Selatan. Patogen diisolasi dari daun tomat yang bergejala bercak daun. Selanjutnya sampel daun dicuci dengan menggunakan air mengalir kemudian dikeringanginkan. Sampel daun tanaman tomat dipotong dengan ukuran $1 \mathrm{~cm}$ persegi dan didesinfeksi dengan cara dicuci dengan alkohol $70 \%$ selama 1 menit, kemudian dibilas dengan aquades dan dikeringanginkan. Potongan daun tanaman tomat yang bergejala diinkubasi ke dalam cawan petri yang telah berisi media PDA. Selanjutnya biakan dalam cawan petri diinkubasi dalam suhu ruang. Hifa patogen yang tumbuh pada media PDA diidentifikasi secara makrokopis dan mikroskopis (Watanabe, 2002). Cendawan patogen Colletotrichum sp. dan Sclerotium sp. yang berhasil diidentifikasi disimpan untuk siap digunakan pada uji selanjutnya.

\section{Peremajaan dan Pemurnian Patogen Colletotrichum sp. dan Sclerotium sp. \\ Patogen Colletotrichum sp. dan Sclerotium} sp. masing-masing dimurnikan kembali dengan menumbuhkan pada medium PDA dalam cawan petri berukuran diameter $9 \mathrm{~cm}$. Biakan diinkubasi pada suhu ruang selama satu minggu, patogen yang telah murni siap digunakan untuk uji daya hambat pestisida nabati pada pengujian selanjutnya (Watanabe, 2002).

\section{Rancangan Penelitian}

Rancangan percobaan yang digunakan adalah Rancangan Acak Lengkap (RAL) dengan 4 perlakuan yaitu fungisida sintetik $2 \mathrm{~mL}(\mathrm{~N} 1)$, phymar $10 \mathrm{~mL}(\mathrm{~N} 2)$, phymar $20 \mathrm{~mL}(\mathrm{~N} 3)$, phymar $30 \mathrm{~mL}$ (N4) masing-masing untuk Colletotrichum sp. dan Sclerotium sp, dan 4 perlakuan yaitu fungisida sintetik $2 \mathrm{~mL}$ (N1), minyak cengkeh 2,5 $\mathrm{mL}$ (N5), minyak cengkeh $5 \mathrm{~mL}$ (N6) dan minyak cengkeh $7 \mathrm{~mL}$ (N7) masing-masing Colletotrichum sp. dan Sclerotium sp. Setiap perlakuan diulang empat kali sehingga terdapat 32 unit perlakuan. Masing-masing bahan fungisida sintetik dan fungisida nabati dilarutkan dalam $1 \mathrm{~L}$ media agar.

\section{Prosedur Penelitian}

Pengambilan Sampel Gejala Hawar Daun Tomat, Isolasi dan Identifikasi Patogen

Pengambilan sampel tanaman tomat yang bergejala hawar/bercak daun dilakukan pada pertanaman tomat di Kecamatan Wolasi Kabupaten Konawe Selatan. Sampel daun tomat yang menunjukkan gejala hawar dimasukkan plastik klip dan diberi label, selanjutnya dimasukkan ke kotak pendingin untuk dibawa ke laboratorium. Isolasi dilakukan dengan cara daun tomat yang bergejala dicuci dengan menggunakan air mengalir dan dikeringanginkan. Sampel daun tanaman tomat dipotong-potong dengan ukuran $1 \mathrm{~cm}$ persegi yang setengah bagian jaringan daun bergejala dan sisanya jaringan daun tomat yang masih sehat. Disinfektasi dilakukan dengan dengan alkohol $70 \%$ selama 1 menit, selanjutnya dibilas dengan aquades dan dikeringanginkan. Potongan daun tersebut diinkubasi ke dalam cawan petri berdiameter $9 \mathrm{~cm}$ yang telah berisi media PDA pada suhu ruang. Hifa patogen yang tumbuh pada media PDA diidentifikasi secara makrokopis dan mikroskopisdengan buku identifikasi (Watanabe, 2002). Patogen yang berhasil diidentifikasi disimpan di lemari pendingin bersuhu $4^{0} \mathrm{C}$ untuk selanjutnya dapat digunakan pada tahap penelitian uji daya hambat fungisida nabati. 


\section{Peremajaan Patogen dan Pengujian Daya Hambat Pestsida Nabati}

Patogen yang telah diidentifikasi sebelumnya ditumbuhkan dan dimurnikan kembali dengan cara yang sama saat tahap identifikasi. Masing-masing pestisida nabati phymar dan minyak cengkeh sesuai dengan dosis uji dicampurkan ke dalam medium PDA dengan menggunakan magnetic stirer selama 5 menit. Setelah itu dituang ke dalam cawan petri berdiameter $9 \mathrm{~cm}$ sebanyak 20 $\mathrm{mL}$ per cawan. Potongan patogen berukuran $1 \mathrm{~cm}^{2}$ berumur 1 minggu diletakkan di bagian tengah medium PDA. Inkubasi dilakukan pada suhu kamar selama 2 minggu atau miselium patogen pada cawan petri-kontrol telah memenuhi cawan petri. Pengamatan dilakukansetiap 2 hari dengan mengukur diameter koloni masing-masing patogen uji pada setiap perlakuan.

\section{Daya Hambat Fungusida Nabati}

Laju pertumbuhan patogen dilakukan dengan mengukur diameter miselium pada cawan petri pada umur $2,4,6,8,10$ dan 12 hari setelah inkubasi.Hasil perhitungan laju pertumbuhan koloni yang terakhir digunakan menghitung daya hambat. Menurut Rai (2006), daya hambat dihitung dengan rumus:

Daya Hambat $(\%)=\frac{\text { Diameter koloni Kontrol }- \text { Diameter koloni Perlakuan }}{\text { Diameter koloni kontrol }} \times 100 \%$

\section{Analisis Data}

Data hasil pengamatan yang diperoleh dianalisis menggunakan sidik ragam. Hasil analisis yang menunjukkan $\quad F_{\text {hitung }}>\quad F_{\text {tabel }}$ dilanjutkan denganUji Jarak Berganda Duncan (UJBD) pada taraf kepercayaan $95 \%$.

\section{HASIL DAN PEMBAHASAN}

\section{Uji Daya Hambat Fungisida Nabati Phymar terhadap Patogen Colletotrichum sp.}

Hasil pengamatan menunjukkan bahwa tingkat daya hambat tertinggi pestisida nabati Phymar pada pengamatan 2 -12 hari setelah inokulasi (HSI) adalah perlakuan N4 dengan rerata tingkat daya hambat yaitu $15,33 \%, 24,46 \%$, $25,79 \%, 25,93 \%, 26,49 \%$ dan $32,52 \%$ yang tidak berbeda nyata dengan perlakuan $\mathrm{N} 2$ dan $\mathrm{N} 3$ dan berbeda nyata dengan N1, sedangkan daya hambat terendah pada perlakuan N1 dengan rerata tingkat daya hambat yaitu $8,71 \%, 9,13 \%, 9,38 \%, 10,83 \%$, 12,33\% dan 20,35\% (Tabel 1).

Pestisida nabati dapat menekan kejadian penyakit, diduga pestisida nabati mengandung bahan aktif/bioaktif seperti alkaloid, terpenoid, fenolik, dan zat-zat kimia sekunder lainnya yang dapat menghambat dan merusak sel mikroorganisme. Uji daya hambat fungisida nabati phymar terhadap patogen Colletotrichum sp. menunjukkan bahwa perlakuan fungisida nabati Phymar pada konsentrasi $30 \mathrm{ml}$ (N4) dapat menghambat perkembangan miselium Colletotrichum sp. sebesar 32,52\%. Hasil ini sejalan dengan penelitian Mariadi et al.(2018) bahwa perlakuan fungisida nabati Phymar dengan konsentrasi $20 \mathrm{ml} / \mathrm{L}$ air efektif menurunkan intensitas serangan penyakit busuk buah kakao dari serangan sangat berat $(36,43 \%-78,57 \%)$ menjadi ringan $(6,43 \%)$. Lebih lanjut dijelaskan bahwa aplikasi pestisida nabati tersebut pada konsentrasi tanpa pengenceran dan $20 \mathrm{cc} / 1$ air dapat menyembuhkan penyakit kanker batang 100\% masing-masing dalam 2 dan 4 hari setelah aplikasi.

Tabel 1. Rata-rata tingkat daya hambat pertumbuhan Colletotrichum sp. pada berbagai konsentrasi pestisida nabati Phymar

\begin{tabular}{ccccccc}
\hline \multirow{2}{*}{ Perlakuan } & \multicolumn{6}{c}{ Rerata tingkat daya hambat (\%) pada pengamatan hari ke- } \\
& 2 & 4 & 6 & 8 & 10 & 12 \\
\hline N1 & $8,71 \mathrm{~b}$ & $9,13 \mathrm{~b}$ & $9,38 \mathrm{~b}$ & $10,83 \mathrm{~b}$ & $12,33 \mathrm{~b}$ & $20,35 \mathrm{~b}$ \\
N2 & $7,47 \mathrm{~b}$ & $22,54 \mathrm{a}$ & $24,40 \mathrm{a}$ & $24,86 \mathrm{a}$ & $25,41 \mathrm{a}$ & $30,98 \mathrm{a}$ \\
N3 & $13,95 \mathrm{a}$ & $23,46 \mathrm{a}$ & $24,48 \mathrm{a}$ & $25,28 \mathrm{a}$ & $25,83 \mathrm{a}$ & $31,48 \mathrm{a}$ \\
N4 & $15,33 \mathrm{a}$ & $24,46 \mathrm{a}$ & $25,79 \mathrm{a}$ & $25,93 \mathrm{a}$ & $26,49 \mathrm{a}$ & $32,52 \mathrm{a}$ \\
\hline & $2=1,93$ & $2=3,18$ & $2=4,22$ & $2=3,92$ & $2=3,68$ & $2=5,34$ \\
UJBD 5\% & $3=2,03$ & $3=3,33$ & $3=4,43$ & $3=4,11$ & $3=3,85$ & $3=5,60$ \\
& $4=2,08$ & $4=3,43$ & $4=4,55$ & $4=4,23$ & $4=3,96$ & $4=5,76$ \\
\hline
\end{tabular}

Keterangan: Angka-angka yang diikuti oleh huruf yang sama pada kolom yang sama tidak berbeda nyata pada UJBD 0,05.N1=fungisida sintetik $2 \mathrm{~mL}, \mathrm{~N} 2=$ pestisida nabati phymar $10 \mathrm{~mL}, \mathrm{~N} 3=$ pestisida nabati phymar $20 \mathrm{~mL}$, N4= pestisidaa nabati phymar $30 \mathrm{ml}$. 


\section{Daya Hambat Fungisida Nabati Phymar terhadap Patogen Sclerotium sp.}

Hasil pengamatan menunjukkan bahwa tingkat daya hambat berbagai konsentrasi fungisida nabati phymar pada pengamatan 2 - 12 HSI yang tertinggi pada perlakuan N4 dengan rerata tingkat hambat yaitu $84,25 \%, 78,62 \%, 70,55 \%, 63,27 \%$, $52,27 \%$ dan $40,67 \%$ yang berbeda nyata dengan perlakuan N1, N2 dan N3, sedangkan terendah pada perlakuan $\mathrm{N} 1$ dengan rerata tingkat daya hambat yaitu $4,62 \%, 3,37 \%, 2,82 \%, 2,02 \%, 1,13 \%$ dan $0,29 \%$ (Tabel 2).

\section{Daya Hambat Fungisida Nabati Minyak Cengkeh terhadap Patogen Colletotrichum sp.}

Hasil pengamatan menunjukkan bahwa tingkat daya hambat berbagai konsentrasi fungisida nabati minyak cengkeh pengamatan 2 sampai 12 HSI yang tertinggi pada perlakuan N2, N3 dan N4 dengan rerata tingkat hambat yaitu $100 \%$, yang berbeda nyata dengan perlakuan $\mathrm{N} 1$, sedangkan terendah pada perlakuan $\mathrm{N} 1$ dengan rerata tingkat daya hambat yaitu $8,71 \%, 9,13 \%, 9,75 \%, 11,43 \%$, $12,16 \%$ dan $21,02 \%$ (Tabel 3).

Tabel 2. Rata-rata tingkat daya hambat pertumbuhan Sclerotium sp. pada berbagai konsentrasi fungisida nabati Phymar

\begin{tabular}{ccccccc}
\hline \multirow{2}{*}{ Perlakuan } & \multicolumn{6}{c}{ Rerata tingkat daya hambat $(\%)$ pada pengamatan hari ke- } \\
& 2 & 4 & 6 & 8 & 10 & 12 \\
\hline N1 & $4,62 \mathrm{~d}$ & $3,37 \mathrm{~d}$ & $2,82 \mathrm{~d}$ & $2,02 \mathrm{~d}$ & $1,13 \mathrm{c}$ & $0,29 \mathrm{c}$ \\
$\mathrm{N} 2$ & $51,84 \mathrm{c}$ & $42,10 \mathrm{c}$ & $27,99 \mathrm{c}$ & $9,00 \mathrm{c}$ & $2,00 \mathrm{c}$ & $0,54 \mathrm{c}$ \\
N3 & $67,32 \mathrm{~b}$ & $53,65 \mathrm{~b}$ & $37,48 \mathrm{~b}$ & $26,18 \mathrm{~b}$ & $12,31 \mathrm{~b}$ & $9,63 \mathrm{~b}$ \\
N4 & $84,25 \mathrm{a}$ & $78,62 \mathrm{a}$ & $70,55 \mathrm{a}$ & $63,27 \mathrm{a}$ & $52,27 \mathrm{a}$ & $40,67 \mathrm{a}$ \\
\hline & $2=2,00$ & $2=6,65$ & $2=5,56$ & $2=3,24$ & $2=2,53$ & $2=4,81$ \\
UJBD 5\% & $3=2,09$ & $3=6,98$ & $3=5,82$ & $3=3,40$ & $3=2,65$ & $3=5,04$ \\
& $4=2,15$ & $4=7,18$ & $4=5,99$ & $4=3,49$ & $4=2,73$ & $4=5,18$ \\
\hline
\end{tabular}

Keterangan: Angka-angka yang diikuti oleh huruf yang sama pada kolom yang sama tidak berbeda nyata pada UJBD $0,05 . \mathrm{N} 1=$ fungisida sintetik $2 \mathrm{~mL}, \mathrm{~N} 2=$ pestisida nabati phymar $10 \mathrm{~mL}, \mathrm{~N} 3=$ pestisida nabati phymar $20 \mathrm{~mL}, \mathrm{~N} 4=$ pestisida nabati phymar $30 \mathrm{~mL}$

Tabel 3. Rata-rata tingkat daya hambat pertumbuhan Colletotrichum sp. pada berbagai konsentrasi fungisida nabati minyak cengkeh

\begin{tabular}{ccccccc}
\hline \multirow{2}{*}{ Perlakuan } & \multicolumn{6}{c}{ Rerata tingkat daya hambat (\%) pada pengamatan hari ke- } \\
& 2 & 4 & 6 & 8 & 10 & 12 \\
\hline N1 & $8,71 \mathrm{~b}$ & $9,13 \mathrm{~b}$ & $9,75 \mathrm{~b}$ & $11,43 \mathrm{~b}$ & $12,16 \mathrm{~b}$ & $21,02 \mathrm{~b}$ \\
N5 & $100,00 \mathrm{a}$ & $100,00 \mathrm{a}$ & $100,00 \mathrm{a}$ & $100,00 \mathrm{a}$ & $100,00 \mathrm{a}$ & $100,00 \mathrm{a}$ \\
N6 & $100,00 \mathrm{a}$ & $100,00 \mathrm{a}$ & $100,00 \mathrm{a}$ & $100,00 \mathrm{a}$ & $100,00 \mathrm{a}$ & $100,00 \mathrm{a}$ \\
N7 & $100,00 \mathrm{a}$ & $100,00 \mathrm{a}$ & $100,00 \mathrm{a}$ & $100,00 \mathrm{a}$ & $100,00 \mathrm{a}$ & $100,00 \mathrm{a}$ \\
\hline \multirow{2}{*}{ UJBD 5\% } & $2=3,28$ & $2=4,18$ & $2=2,61$ & $2=3,30$ & $2=3,81$ & $2=4,11$ \\
& $3=3,44$ & $3=4,38$ & $3=2,74$ & $3=3,46$ & $3=3,99$ & $3=4,31$ \\
& $4=3,54$ & $4=4,51$ & $4=2,82$ & $4=3,56$ & $4=4,11$ & $4=4,43$ \\
& $5=3,60$ & $5=4,60$ & $5=2,87$ & $5=3,63$ & $5=4,19$ & $5=4,51$ \\
\hline
\end{tabular}

Keterangan: Angka-angka yang diikuti oleh huruf yang sama pada kolom yang sama tidak berbeda nyata pada UJBD $0,05 . \mathrm{N} 1=$ fungisida sintetik $2 \mathrm{~mL}, \mathrm{~N} 5=$ fungisida nabati minyak cengkeh $2,5 \mathrm{~mL}, \mathrm{~N} 6=$ fungisida nabati minyak cengkeh $5 \mathrm{~mL}, \mathrm{~N} 7=$ fungisida nabati minyak cengkeh $7,5 \mathrm{~mL}$.

Tumbuhan memiliki potensi sebagai pestisida nabati karena mensintesis senyawa metabolit sekunder yang memiliki kemampuan menekan pertumbuhan patogen. Metabolit sekunder tersebut dapat berupa alkaloid, terpenoid, fenol, flavonoid, minyak atsiri, tanin, dan lain sebagainya 
(Tampubolon et al., 2018). Hasil percobaan menunjukkan bahwa semua media PDA yang dicampur dengan fungisida nabati minyak cengkeh dapat menghambat pertumbuhan miselium patogen uji. Diduga kuat kandungan eugenol pada minyak cengkeh kerusakan pada hifa cendawan sehingga pertumbuhannya terhambat. Dilaporkan bahwa konsentrasi minyak atsiri pada bunga cengkeh mencapai $10-20 \%$, tangkai $5-10 \%$, dan daun $1-4 \%$, dengan kandungan eugenol mencapai $70-80 \%$ (Nurdjannah, 2004). Rana et al. (2011) bahwa minyak cengkeh menyebabkan lisis pada miselium dan spora cendawan melalui pengamatan dengan mikroskop. Diinformasikan eugenol tersebut mempunyai sifat antifungi pada cendawan Fusarium moniliforme NCIM 1100, F. oxysporum MTCC 284, dan Aspergillus sp. Juga terbukti mampu menghambat pertumbuhan dan biomassa cendawan Botryodiplodia sp. secara in-vitro dengan rata-rata penghambatan sebesar $45,44 \%$ pada media PDA (Radilla, 2019).

\section{Daya Hambat Fungisida Nabati Minyak Cengkeh terhadap Patogen Sclerotium sp.}

Berdasarkan Tabel 3 dan 4 dapat diketahui bahwa seluruh perlakuan konsentrasi minyak cengkeh mampu menghambat pertumbuhan miselium cendawan Colletotrichum sp. dan Sclerotium sp. hingga miselium sama sekali tidak tumbuh hingga akhir pengamatan. Persentase penghambatan (Tabel 3 dan 4) juga menunjukkan penghambatan sebesar $100 \%$ untuk semua perlakuan minyak daun cengkeh dari awal hingga akhir pengamatan. Kemampuan daya hambat yang dimiliki minyak cengkeh dipengaruhi oleh kandungan senyawa bioaktif eugenol. Kandungan eugenol yang dimiliki bisa mencapai $72,90 \%$, selain itu minyak daun cengkeh juga mengandung asetil eugenol, betacaryophyllene dan vanillin, asam krategolat, tanin, asam galotanat, metil salisilat, flavonoid, dan triterpenoid (Bhowmik et al. 2012).

Tabel 4. Rata-rata tingkat daya hambat pertumbuhan Sclerotium sp. pada berbagai konsentrasi fungisida nabati minyak cengkeh

\begin{tabular}{ccccccc}
\hline \multirow{2}{*}{ Perlakuan } & \multicolumn{6}{c}{ Rerata tingkat daya hambat $(\%)$ pada pengamatan hari ke- } \\
& 2 & 4 & 6 & 8 & 10 & 12 \\
\hline N1 & $4,62 \mathrm{~b}$ & $3,37 \mathrm{~b}$ & $2,82 \mathrm{~b}$ & $2,02 \mathrm{~b}$ & $1,13 \mathrm{~b}$ & $0,29 \mathrm{~b}$ \\
N5 & $100,00 \mathrm{a}$ & $100,00 \mathrm{a}$ & $100,00 \mathrm{a}$ & $100,00 \mathrm{a}$ & $100,00 \mathrm{a}$ & $100,00 \mathrm{a}$ \\
N6 & $100,00 \mathrm{a}$ & $100,00 \mathrm{a}$ & $100,00 \mathrm{a}$ & $100,00 \mathrm{a}$ & $100,00 \mathrm{a}$ & $100,00 \mathrm{a}$ \\
N7 & $100,00 \mathrm{a}$ & $100,00 \mathrm{a}$ & $100,00 \mathrm{a}$ & $100,00 \mathrm{a}$ & $100,00 \mathrm{a}$ & $100,00 \mathrm{a}$ \\
\hline \multirow{2}{*}{ UJBD 5\% } & $2=2,28$ & $2=3,01$ & $2=0,77$ & $2=1,29$ & $2=1,18$ & $2=0,44$ \\
& $3=2,98$ & $3=3,15$ & $3=0,18$ & $3=1,35$ & $3=1,24$ & $3=0,46$ \\
& $4=3,07$ & $4=3,24$ & $4=0,83$ & $4=1,39$ & $4=1,28$ & $4=0,47$ \\
& $5=3,13$ & $5=3,30$ & $5=0,84$ & $5=1,41$ & $5=1,30$ & $5=0,48$ \\
\hline
\end{tabular}

Keterangan : Angka-angka yang diikuti oleh huruf yang sama pada kolom yang sama tidak berbeda nyata pada UJBD 0,05. N1= fungisida sintetik $2 \mathrm{~mL}, \mathrm{~N} 5=$ fungisida nabati minyak cengkeh 2,5 mL, N6= fungisida nabati minyak cengkeh $5 \mathrm{~mL}, \mathrm{~N} 7=$ fungisida nabati minyak cengkeh 7,5 mL.

Hal tersebut didukung oleh pernyataan Manohara dan Noveriza (1999) yang menyebutkan bahwa minyak daun cengkeh mengandung eugenol dan senyawa ini bersifat antifungi karena mampu merusak dinding sel cendawan dengan cara mengganggu penyusun dinding sel pada cendawan tersebut. Eugenol memiliki kemampuan melarutkan lemak yang terdapat pada dinding sel jamur sehingga dinding sel menjadi rusak dan mengganggu permeabilitas sel jamur. Sebagai akibatnya, dinding sel menjadi tidak selektif sehingga terjadi penekanan pertumbuhan dan perkembangan jamur patogen (Novita, 2008). Harni
(2013) lebih lanjut menjelaskan aktivitas antimikroba dari eugenol dipengaruhi kandungan senyawa fenolik berupa gugus alkil sekunder dan gugus $\mathrm{OH}$ yang sangat reaktif membentuk ikatanhidrogen dengan enzim, Salah satu enzim yang berperan dalam merusak dinding sel jamur adalah enzim kitinase. Park et al. (2007) menemukan kerusakan membran mitokondria secara parsial dan kerusakan dinding sel cendawan Trichophyton mentagrophytes secara sempurna setelah diberi dengan eugenol.

Berdasarkan hasil penelitian Hizrianti dan Dewi (2021) minyak daun cengkeh pada 
konsentrasi $\quad 0,065 \%$ dapat menghambat pertumbuhan miselium cendawan Alternaria solani dengan persentase penghambatan sebesar $100 \%$. Untari (2003), melaporkan fungisida minyak cengkeh lebih efektif dalam menghambat perkembangan patogen Colletotrichum capsici secara in-vitro, hal yang sama juga ditunjukkan pada hasil penelitian Syamsuddin (2002) bahwa penggunaan penggunaan minyak cengkeh lebih efektif dalam menghambat pertumbuhan patogen C.capsici. Pada konsentrasi $0,06 \%$ minyak cengkeh mampu menghambat pertumbuhan C.capsici $100 \%$.

\section{KESIMPULAN}

Berdasarkan hasil penelitian yang telah dilaksanakan maka dapat disimpulkan bahwa perlakuan pestisida nabati phymar dan minyak cengkeh mampu menghambat pertumbuhan cendawan patogen Colletotrichum sp. dan Sclerotium sp. Pestisida nabati minyak cengkeh dengan konsentrasi $2,5 \mathrm{ml} / \mathrm{L}$ media agar efektif menghambat perkembangan Colletotrichum sp. dan Sclerotium sp. secara in-vitro dengan daya hambat masing-masing sebesar $100 \%$.

\section{UCAPAN TERIMA KASIH}

Terima kasih disampaikan kepada Badang Litbang Pertanian Kementerian Pertanian RI atas dukungan dana melalui Penelitian Kemitraan sesuai surat perjanjian pelaksanaan kegiatan Nomor : 504.4/PL.040/H.1/03/2020.K Tanggal : 26 Maret 2020. Ucapan yang sama disampaikan kepada LPPM Universitas Halu Oleo atas dukungan selama kegiatan serta terima kasih disampaikan kepada mahasiswa dan petani yang membantu penelitian di lapang

\section{DAFTAR PUSTAKA}

Akarapisan A, A. Kumvinit, and S. Ruamrungsri. 2017. Bulb Rot of Amaryllis Caused by Sclerotium rolfsiiand Effect of Fungicides on In-Vitro Inhibition of Mycelial Growth. Asian J Plant Pathol. 11(2): 95-101. DOI: https://doi.org/10.3923/ ajppaj.2017.95.101.

Anggraeni, I. 2009. Colletotrichum sp. Penyebab Penyakit Bercak Daun pada Beberapa Bibit Tanaman Hutan Di Persemaian. Mitra Hutan Tanaman, 4(1): 29-35 https://ejournal.forda-mof.org/ejournallitbang/index.php/JWAS/article/download/8 $43 / 818$
Bhowmik, D., K. Kumar, P. S. Yadav, A., S. Srivastava, S. Paswan, and A. S. Dutta. 2012. Recent Trends in Indian Traditional Herbs Syzygium aromaticum and its Health Benefits. Journal of Pharmacognosy and Phytochemistry, 1(1): 6-17. www.phytojournal.com

Emilda, D. dan M. Istianto. 2011. Pengaruh Minyak Cengkeh terhadap Pertumbuhan Koloni dan Sifat Antagonis Cendawan Gliocladium sp. terhadap Fusarium oxysporum f. sp. cubense. J. Hort. 21(1):33-39, 2011. http://dx.doi.org/10.21082/jhort.v21n1.20 11.p33-39

Ferreira, S.A., and R.A. Boley. 2006. Sclerotium rolfsii. URL:http://www. Extento.edu (diakses 26 november 2013).

Food and Agriculture Organization (FAO). 2010. Nutrition and Food System Division. [Internet] [diunduh 2017 Agustus 28] tersedia pada www.fao.org

Gulzar, N., A.N. Kamili, and M.Y. Mir. 2018. The Process of Early Blight Disease Development in Tomato. Journal of Research and Development, 18:112-115. http://cord.uok.edu.in/Files/4701b853a330-4f94-a00e01555a32a0ff/Journal/c85f46fb-a424-4505b06f-4d8848b2b86a.pdf

Gusnawaty, H.S dan Mariadi. 2013. Pengendalian Penyakit Diplodia (Botryodiplodia theobromae pat) Pada Tanaman Jeruk dengan Pestisida Nabati (Phymar C SL) di Sulawesi Selatan. Agriplus. 23(2): 08540128. https://adoc.pub/pengendalian penyakit-diplodia-botryodiplodiatheobromae-pat.html

Hadizadeh I., B. Peivastegan, and $\mathrm{H}$. Hamzehzarghani. 2009. Antifungal Activity of Essential oils From Some Medicinal Plants of Iran Against Alternaria alternate. American Journal of Applied Sciences, 6(5): 857-861.

https://thescipub.com/html/10.3844/ajassp.2 009.857 .861

Harni,R.,A.Widi,dan Supriadi, 2013. Keefektifan Beberapa Formula Fungisida Nabati Eugenol dan Sitronella terhadap Phytophthora palmivora asal Kakao. Buletin RISTI 4(1):11-18. 
https://onesearch.id/Record/IOS3610.article -2344 ? widget $=1 \&$ repository $\mathrm{id}=3610$

Hizrianti, dan S. Dewi. 2021. Uji Daya Hambat Minyak Daun Cengkeh dan Ekstrak Daun Pepaya terhadap Cendawan Alternaria solani (Ell \& Mart) Sorauer Pada Tomat Secara In-vitro. Jurnal Media Pertanian, 6(1): 30-44. ISSN: 2085-4226. e-ISSN: 2745-8946.

http://jurnal.unsil.ac.id/index.php/medperta nian/article/view/3011

Istianto, M. and D. Emilda.2008. Preliminary Study of Antifungal Activity of Some Essential oils AgainstFusarium oxysporum f. sp. cubense Causing Banana Wilt Disease. Laporan Hasil Penelitian TA 2007. 14: 33-38. http://www.inhort.pl/files/journal_pdf/journ al 2011 2/full11\%202011(2).pdf

Kementan. 2020. Statistik Pertanian, Kementerian Pertanian, Jakarta

Kronstad, J.W. 2000. Fungal pathology. Klower Academic Publishers. Nederlands. Hal 112120. http://ejournal.forda-mof.org/ejournallitbang/files/journals/13/articles/843/submis sion/editor/843-1703-1-ED.doc

Manohara, D dan R. Noveriza 1999. Potensi tanaman rempah dan obat sebagai pengendali patogen Phytophthora capsisi dalam Prosiding Forum Komunikasi Ilmiah Pemanfaatan Pestisida Nabati, Bogor 9-10 November 1999. Hlm. 406-422

Mariadi, Nuriadi, T Pakki, dan Gusnawaty. 2018. Pengujian Lapangan Efikasi Fungisida Alami Phymar C SL Untuk Pengendalian Penyakit Busuk Buah dan Kanker Batang pada Kakao di Kabupaten Luwu Utara. abstract.http://dx.doi.org/10.33297/jbs.vli1. 2018.21-38

Novita,T. 2008.Peran Daun Cengkeh Terhadap Pengendalian Layu Fusarium Pada Tanaman Tomat.Jurnal Agronomi, 12(2):227-235. Jambi.

https://jurnal.agrosainta.id/index.php/ags/art icle/download/32/31

Nurdjannah, N. 2004. Diversifikasi penggunaan cengkeh. Jurnal Perspektif, 3(2): 61-70. http://ejurnal.litbang.pertanian.go.id/index.p $\mathrm{hp} / \mathrm{psp} /$ article/viewFile/5584/4759

Park, M.J., K.S Gwak, I.Yang, W.S. Choi, H.J. Jo, J.Q. Chang, E.B. Jeung and I.G. Choi. 2007. Antifungal activities of the essential oils in Syzygium aromaticum (L.) Merr. Et Perry and Leptospermum petersonii Bailey and their constituents against various dermatophytes. The J. Microbiol., 45, 460-465. https://www.koreascience.or.kr/article/JAK O200735822306545.pdf

Radilla, N.2019. Uji Efektivitas Minyak Atsiri Kunyit dan Cengkeh dalam Penghambatan Patogen Botryodiplodia sp. secara In-Vitro. Skripsi, Fakultas Kehutanan, Institut Pertanian Bogor.

http://repository.ipb.ac.id/handle/12345678 9/99168

Rai, I. G. A. 2006. Aktivitas fungisida ekstrak daun saba (Piper majusculum Blume) terhadap jamur Fusarium oxysporum f. sp. vanillae, penyebab penyakit Busuk Batang pada Panili. Tesis. Program Magister Program Studi Bioteknologi Universitas Udayana. https://simdos.unud.ac.id/uploads/file_penel itian_1_dir/3a3dbc40d3c17a27365b9cbfedd dc3c7.pdf

Rana, I. S, A. S.Rana, dan R. C. Rajak. 2011. Evaluation Of Antifungal Activity In Essential Oil of The Syzygium aromaticum (L.) by Extraction, Purification and Analysis Of Its Main Component Eugenol. Brazilian Journal of Microbiology, 42(4):1269-1277.

https://www.researchgate.net/publication/25 6542234

Semangun, H. 2007. Penyakit-penyakit Tanaman Hortikultura di Indonesia, Edisi ke2.Gadjah Mada University Press, Yogyakarta.

https://ugmpress.ugm.ac.id/id/product/tekno logi-pertanian/penyakit-penyakit-tanamanhortikultura-di-indonesia

Susana,Tjut C, dan P.Arisandi. 2010. Dosis dan Produksi Kascing untuk Pengendalian Penyakit Layu Fusarium pada Tanaman Tomat. Jurusan Hama dan Penyakit Tumbuhan Fakultas Pertanian Universitas Unsyah Banda Aceh. J. Floratek, 5: 152-163. http://jurnal.unsyiah.ac.id/floratek/article/vi ew/400/384

Sukamto dan D. Wahyuno. 2016. Identifikasi dan Karakterisasi Sclerotium rolfsii Sacc. Penyebab Penyakit Busuk Batang Nilam (Pogostemon Cablin Benth) Bul Littro., 24(1): 35-41.

DOI:10.21082/bullittro.v24n1.2013.\%p 
Soare, R M, Dinu, and C. Babeanu. 2018. The Effect Of Using Grafted Seedlings On The Yield and Quality of Tomatoes Grown In Green Houses.Hort. Sci,45(2): 76-82. https://doi: 10.17221/214/2016-HORTSCI

Syamsuddin, 2002. Pengendalian Penyakit Terbawa Benih (Seedborn Disease) pada Tanaman Cabai (Capsicumannum L.) Menggunakan Agen Biokontrol dan Ekstrak Botani. Program Pacasarjana, IPB. Bogor.

Tampubolon, K., F.N. Sihombing, dan Z. Purba. 2018. Potensi Metabolit Sekunder Gulma sebagai Pestisida Nabati Di Indonesia.Kultivasi, 17(3): 683-693. https://doi.org/10.24198/kultivasi.v17i3.1 8049.

Wasonowati. 2011. Meningkatkan Pertumbuhan Tanaman Tomat (Lycopersicon esculentum) dengan Sistem Budidaya Hidroponik. Jurnal Agrovigor, 4(1): 1-8. https://journal.trunojoyo.ac.id/public/journa 1s/11/pageHeaderTitleImage_en_US.png

Watanabe ,T.2002.Pictorial Atlas of Soil and Seed Fungi: Morphologies Of Cultured Fungi and Key to Species. Boca Raton: CRC Press LLC. U.S.A.

http://fmedicine.ajums.ac.ir/_fmedicine/Doc uments/Pictorial $\% 20$ Atlas $\% 20$ of $\% 20$ Soil $\%$ 20and\%20Seed\%20Fungi\%20Morphologie s\%20of\%20Cultured $\% 20$ Fungi $\% 20$ and $\% 20$ Key\%20to\%20Species\%20Second\%20Edit ion_20130415_103243.pdf

Zainal, A., A.Anwar, S. Ilyas, dan Giyanto. 2010. Efektifitas Ekstrak Tumbuhan untuk Mengeliminasi Clavibacter Michiganensis Subsp. Michiganensis pada Benih Tomat. $J$ Agron Indonesia, 38(1):52-59. https://media.neliti.com/media/publications/ 7832-none-821 eadd0.pdf 